\title{
Immobilized Thiosalicylic Ligand System Potentials for the Detoxification of Some Heavy Metals from Tannery Wastewater
}

\author{
Bulus Habila ${ }^{1, ~ *, ~ E m m a n u e l ~ C h i d i e b e r e ~ E z e h ², ~ S i m o n ~ M o s e s ~ S a i d u ~}{ }^{3}$, John Chidozie Attah ${ }^{2}$, \\ Paul Okechukwu Nsude ${ }^{2}$, Emmanuel Agboeze ${ }^{2}$, Ike Christian Ozoemena ${ }^{2}$, \\ Jonathan Danladi Gaiya ${ }^{1}$, Tachye Ninnat Bwankhot Shekarri ${ }^{1}$, Sunday Ture Dahiru ${ }^{1}$, \\ Olajide Joseph Igbehinadun ${ }^{1}$ \\ ${ }^{1}$ Department of Leather and Leather Products/Polymer, Nigerian Institute of Leather and Science Technology, Zaria, Nigeria \\ ${ }^{2}$ Department of Pure and Industrial Chemistry, Enugu State University of Science and Technology, Enugu, Nigeria \\ ${ }^{3}$ National Institute of Hospitality and Tourism, Kaduna Campus, Kaduna, Nigeria \\ Email address: \\ bulus1973@gmail.com (B. Habila) \\ ${ }^{*}$ Corresponding author
}

\section{To cite this article:}

Bulus Habila, Emmanuel Chidiebere Ezeh, Simon Moses Saidu, John Chidozie Attah, Paul Okechukwu Nsude, Emmanuel Agboeze, Ike Christian Ozoemena, Jonathan Danladi Gaiya, Tachye Ninnat Bwankhot Shekarri, Sunday Ture Dahiru, Olajide Joseph Igbehinadun. Immobilized Thiosalicylic Ligand System Potentials for the Detoxification of Some Heavy Metals from Tannery Wastewater. Science Journal of Chemistry. Vol. 9, No. 3, 2021, pp. 72-79. doi: 10.11648/j.sjc.20210903.13

Received: April 20, 2021; Accepted: May 20, 2021; Published: June 29, 2021

\begin{abstract}
Polysiloxanes are characterized by silicon and oxygen backbone and are hydrophobic in nature with low moisture uptake widely used for medical applications. Polysiloxane immobilized thiosalicylic acid ligand system has been prepared through sol-gel method, gelation was observed after 40 minutes. The immobilized ligand was characterized using FTIR, the spectrum showed characteristic absorption bands $\left(\mathrm{cm}^{-1}\right)$ at: $3377(\mathrm{OH}), 2981(\mathrm{C}-\mathrm{H}$ stretch); $2631(\mathrm{SH}) ; 1587$ to $1684(\mathrm{C}=\mathrm{C}$, $\mathrm{C}=\mathrm{O}) ; 1032$ to $1144(\mathrm{Si}-\mathrm{O})$ respectively. SEM analysis showed irregular particle sizes of the polysiloxane matrices while EDX elemental composition gave (wt \%): 3-CPPS; Si (50.45), O (25.02) and Cl (24.57). F - 3CPPS showed, O (58.68), Si (41.32); thiosalicylic (7.14 of S). The extraction of metal ions $\left(\mathrm{Cr}^{3+}, \mathrm{Fe}^{3+}, \mathrm{Pb}^{2+}, \mathrm{Cu}^{2+}\right.$ and $\left.\mathrm{Zn}^{2+}\right)$ were studied using Microwave Plasma Atomic Emission Spectrophotometer (Agilent MPAES-4200) at $\mathrm{pH}$ 6.0. Thermodynamic range with respect to $\mathrm{Cr}^{3+}$, $\mathrm{Fe}^{3+}, \mathrm{Pb}^{2+}, \mathrm{Cu}^{2+}$ and $\mathrm{Zn}^{2+}$ yielded negative values for $\Delta \mathrm{G}^{\circ}$ : $\mathrm{Cu}^{2+}-(11.483$ to 14.842$)$ to $\mathrm{Zn}^{2+}$-(14.368 to 14.842$) \mathrm{KJmol}^{-1}$; positive values for $\Delta \mathrm{H}^{\circ}: \mathrm{Fe}^{3+}(0.000)$ to $\mathrm{Pb}^{2+}(105.130) \mathrm{KJmol}^{-1}$ and $\Delta \mathrm{S}^{0}: \mathrm{Zn}^{2+}$ (47.421) to $\mathrm{Pb}^{2+}$ (389.328)Jmol $\mathrm{J}^{1}$ respectively, indicating spontaneous, endothermic reactions and high degree of disorderliness with respect to metal ion binding capacity to the ligand system.
\end{abstract}

Keywords: Tannery Wastewater, Detoxification, Polysiloxane, Nanomers, Thiosalicylic Ligand

\section{Introduction}

Leather industry generates harmful wastes into water bodies [1]. During tanning alone about $300 \mathrm{~kg}$ of chemicals are added per ton of hides or skins with large volume of water and sludge generated $[2,3]$. Not more than $20 \%$ of the chemicals are absorbed by leather; the remainder flows out with the effluent [4]. Conventional methods used have limitations such as production of toxic sludge [5] and inability to remove heavy metals at trace level, this prompted the use of polymeric modified surfaces with good thermal, mechanical and chemical stability properties such as polysiloxane immobilized with ligands [6] have been employed as a recyclable extractants for heavy metals. These immobilized ligand system could be synthesized directly by sol gel or by chemical modification of the prepared functionalized polysiloxane [6]. A variety of analytical techniques have been employed such as Fourier Transform 
Infra-red (FTIR) [7, 8], Nuclear Magnetic Resonance (NMR), Scanning Electron Microscopy (SEM) [9, 10] and Energy Dispersive X-ray Analysis (EDX) [9, 10]. This study described the Immobilization of thiosalicylic acid ligand system and its potential in the purification of tannery wastewater.

\section{Location of the Study Area}

Kano state covers an area extending between latitudes $120^{\circ} 40^{\prime}$ and $100^{\circ} 30^{\prime}$ and longitudes $70^{\circ} 40^{\prime}$ and $90^{\circ} 30^{\prime}$. Climate is tropical wet and dry with mean annual rainfall of $850 \mathrm{~mm}$, and a population of 9.3 million, it is a flat city drained by the Jakara river and several streams (Niger river watershed) and River Challawa (Lake Chad watershed) all are severely polluted by urban and industrial effluents. Kumbotso local government is the area of study and it lies between latitudes $11^{\circ} 50$ 'S to $12^{\circ} \mathrm{N}$ and longitude $8^{\circ} 24^{\prime} \mathrm{W}$ to $8^{\circ} 40^{\prime} \mathrm{E}$. It falls within the Kano State settlement zone bordering the south and west by Madobi Local Government Area, in the Northern west; Rimin-Gado, in the North by Gwale and East by Tarauni local government areas respectively $[11,12]$.

\section{Experimental}

\subsection{Preparation of Polysiloxane Immobilized Thiosalicylic Acid Ligand System (PITSLS)}

The methods of $[13,8,14]$, were adopted. 3Chloropropylpolysiloxane (CPPS) was prepared by reacting tetraethylorthosilicate $(0.1 \mathrm{~mol}, 20.8 \mathrm{~g})$ with 3chloropropyltrimethoxysilane $(0.05 \mathrm{~mol}, 9.936 \mathrm{~g})$ in the presence of methanol $\left(35 \mathrm{~cm}^{3}\right)$ in a solution of sodium hydroxide $\left(\mathrm{NaOH}, 0.42 \mathrm{~mol} / \mathrm{dm}^{3}, 4.95 \mathrm{~cm}^{3}\right)$ [6], stirred for 5 min at $40^{\circ} \mathrm{C}$ and $\mathrm{pH} 10$ (Tricolour Universal $\mathrm{pH}$ Paper). Gelation formed after $40 \mathrm{~min}$. CPPS was functionalized by refluxing with ethylchloroacetate $(0.122 \mathrm{~mol} ; 15 \mathrm{~g})$ and triethylamine $\left(10 \mathrm{~cm}^{3}\right)$ for $12 \mathrm{~h}$ at $110^{\circ} \mathrm{C}$ (RAYPA Digital Drying Oven) [7]. The functionalized product was measured $(3.200 \mathrm{~g})$ and modified using thiosalicylic acid $(0.05 \mathrm{~mol}$; density $1.49 \mathrm{~g} / \mathrm{cm}^{3}$; volume $7.959 \mathrm{~g}$ ) in ethylchloroacetate $\left(0.244 \mathrm{~mol}\right.$; density $1.145 \mathrm{~g} / \mathrm{cm}^{3}$; volume $\left.26.20 \mathrm{~cm}^{3}\right)$ and 5 $\mathrm{cm}^{3}$ of triethylamine in a round-bottomed flask $\left(250 \mathrm{~cm}^{3}\right)$ and refluxed for $12 \mathrm{~h}$ at $383 \mathrm{~K}$, the product formed was filtered, washed successively with $50 \mathrm{~cm}^{3}$ portions of deionized water, methanol and diethyl ether, dried at $383 \mathrm{~K}$ in an oven for $10 \mathrm{~h}$, labelled and dried over $\mathrm{CaCl}_{2}$.

\subsection{Digestion of Tannery Effluent}

Tannery wastewater sample of $1000 \mathrm{~cm}^{3}$ was transferred into a conical flask and evaporated till dried. The dried sample was digested in $10: 1 \quad \mathrm{HNO}_{3}: \mathrm{HClO}_{4}(\mathrm{v} / \mathrm{v})$. White crystals were found in the digested samples and were dissolved in $150 \mathrm{ml}$ double distilled water. The supernatant were filtered using Whatman No.41 filter paper and was read directly with Agilent MPAES-4200 [15]. The total metal contents were determined as described by Parven et al., [16]. No specific speciation was conducted to ascertain the various valencies of the species at the $\mathrm{pH}$ values of 2, 4, 6, 7 and 9 as used in this study.

\subsection{Effect of Adsorbent}

A volume of $60 \mathrm{~cm}^{3}$ solution of the tannery wastewater adjusted at $\mathrm{pH} 6$ (optimum) was transferred into $150 \mathrm{~cm}^{3}$ conical flask and $10 \mathrm{mg}$ of the polysiloxane immobilized thiosalicylic ligand was added and adjusted in a thermostatic multi- shaker (Gallenkamp Model) at $100 \mathrm{rpm}$ for $2 \mathrm{~h}$ at $30^{\circ} \mathrm{C}$. The resultant solutions were filtered using Whatman No.41 and the residual metal concentrations analysed $\left(\mathrm{Cr}^{3+}\right.$, $\mathrm{Fe}^{3+}, \mathrm{Pb}^{2+}, \mathrm{Cu}^{2+}$ and $\mathrm{Zn}^{2+}$ ) using Agilent MPAES-4200 [17, $18,19]$ This procedure was repeated for 20 and $30 \mathrm{mg}$ of polysiloxane immobilized thiosalicylic ligand with mesh size of $(125-150 \mu \mathrm{m})$ respectively.

\subsection{Thermodynamic Studies}

A volume of $60 \mathrm{~cm}^{3}$ solution of the tannery wastewater adjusted at $\mathrm{pH} 6$ (optimum) was transferred into $150 \mathrm{~cm}^{3}$ conical flask and $20 \mathrm{mg}$ of the polysiloxane immobilized thiosalicylic ligand was added and adjusted in a thermostatic multi-shaker (Gallenkamp Model) at $100 \mathrm{rpm}$ for $2 \mathrm{~h}$ at $30^{\circ} \mathrm{C}$. The resultant solutions were filtered using Whatman No.41 and the residual metal concentrations analysed $\left(\mathrm{Cr}^{3+}\right.$, $\mathrm{Fe}^{3+}, \mathrm{Pb}^{2+}, \mathrm{Cu}^{2+}$ and $\left.\mathrm{Zn}^{2+}\right)$ using Agilent MPAES-4200. [17, $19,20]$. This procedure was repeated for temperatures of 35 and $40^{\circ} \mathrm{C}$ respectively.

\section{Results and Discussion}

PITSLS was employed to extract heavy metals in tannery wastewater due to the availability of reactive sites in the polysiloxane matrix (Figure 1.), the protonation of $\mathrm{COOH}$ to $\mathrm{COO}^{-}$by triethylamine, $\mathrm{SH}$ to $\mathrm{S}^{-}$, and the presence of oxy ions contributes to the removal of these heavy metals.

\subsection{SEM/EDX Analysisof PITSLS}

SEM (EVO/LS10-ZEISS) showed irregular particle sizes of the following polysiloxane matrices at various magnifications $(\mu \mathrm{m})$ : 3- chloropropylpolysiloxane (500); functionalized 3-chloropropylpolysiloxane (500) and thiosalicylic immobilized ligand (200) in Figure 3, with the EDX (EVO/LS10-ZEISS). The morphology shows a rough surface with a pore volume of $52.9940 \mathrm{~nm}^{3}$ in Table 1, which provides a better adsorption environment. EDX data of functionalized 3-CPP with immobilized thiosalicylic acid ligand gives $7.14 \mathrm{wt} \%$ of S (Table 2). This is in agreement with the suggested structure of the targeted system and is an indication of successful polymerization by nucleophilic displacement of a halide anion by Brad B [21], which the sulphur atom was originally not on the polymer framework with $7.14 \mathrm{wt} \%$, within the range of $6.1-10.4 \mathrm{wt} \%$ reported by Issa M. E. [7]; 8.0 wt \%, [6]; 4.30-11.30 wt \% El-Nahhal I. M [22]; 3.90- 6.80 wt \% [23] for similar synthesis. The 
value of $7.14 \mathrm{wt} \%$ was obtained because of the availability of reactive sites in Figure 3, which assisted in the immobilization process, with particle size of $3.4397 \pm 1.5659$ $\mathrm{nm}$. This agreed with the nano-particle sizes of silica in the range of $2-5 \mathrm{~nm}$ with an extraordinary surface-to-volume ratio El-Nahhal I. M [22]. This particle size plays a vital role in adsorption of heavy metals in the tannery wastewater. This is in agreement with the suggested structure of the targeted system and is an indication of successful immobilization of the ligand in the polymer matrix as originally there was no sulphur atom on the polymer framework. The $7.14 \mathrm{wt} \%$ was. The presence of thiol in the matrix agrees with the FTIR results presented in Figure 1, as follows: thiol $\left(\mathrm{SH}, 2631 \mathrm{~cm}^{-}\right.$ ${ }^{1}$ ); silicone ( $\mathrm{Si}-\mathrm{O}-\mathrm{Si}, 1032 \mathrm{~cm}^{-1}$ ) Figure 2.

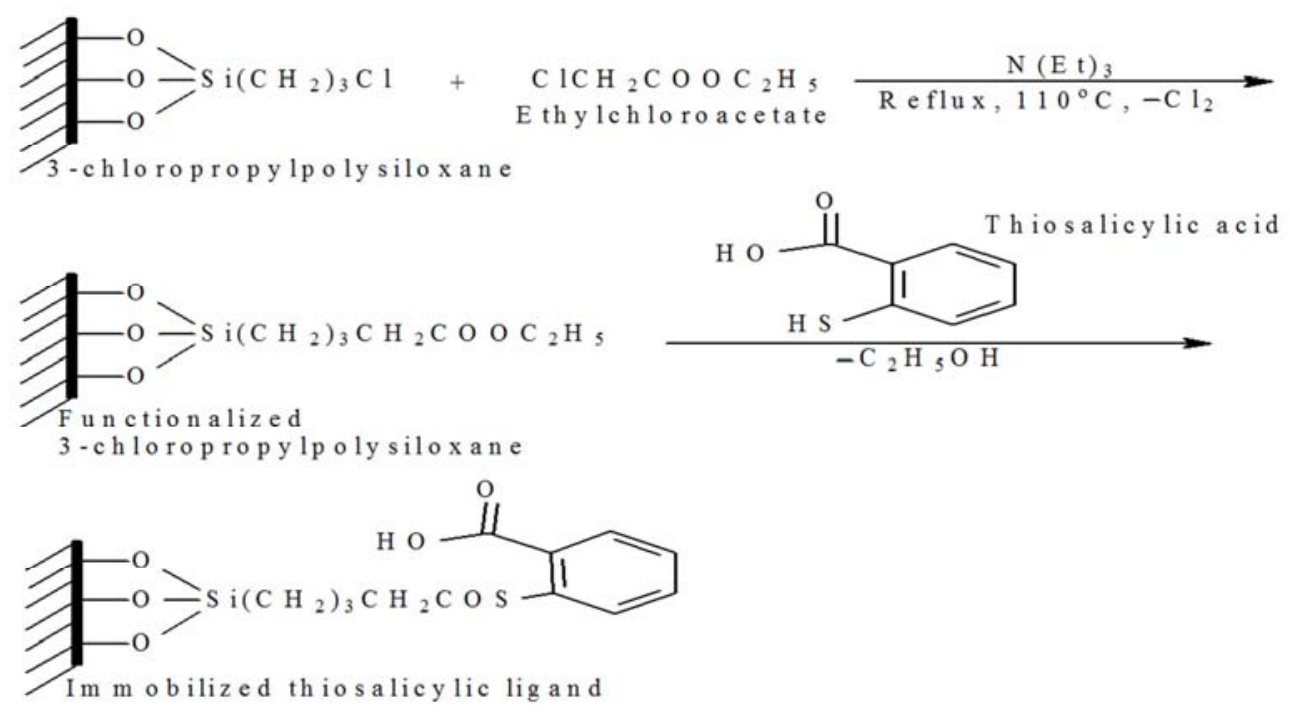

Figure 1. Preparation of thiosalicylic acid ligand system.

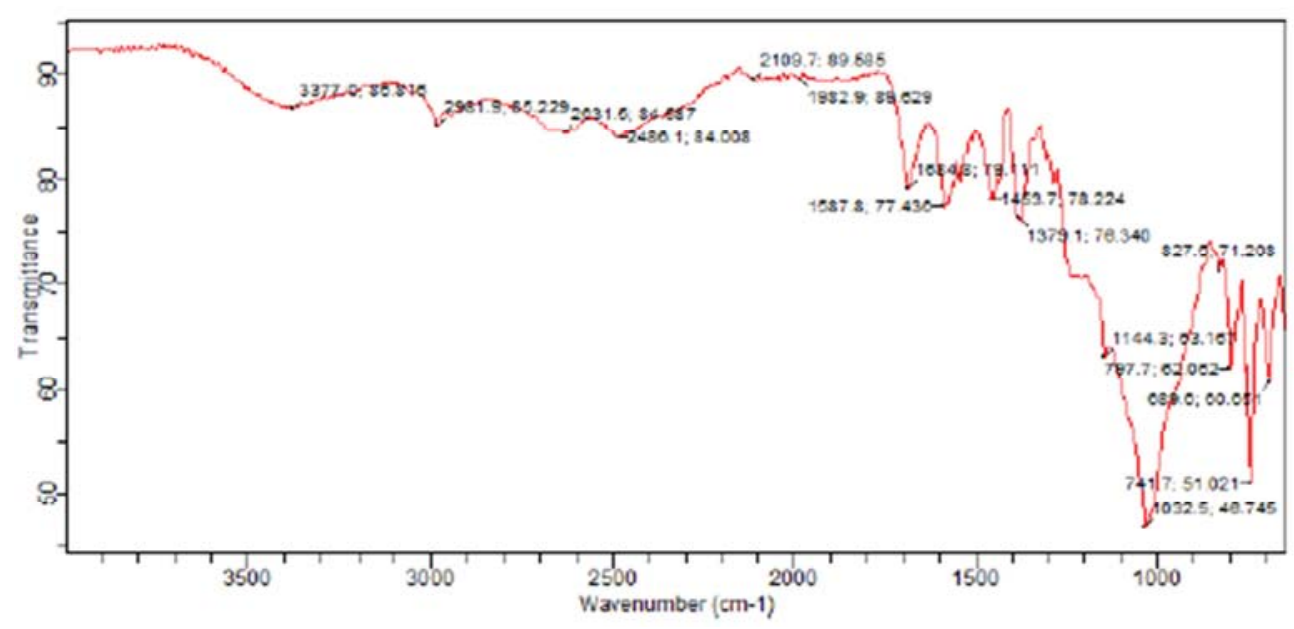

Figure 2. FTIR Spectrum for PITSLS.

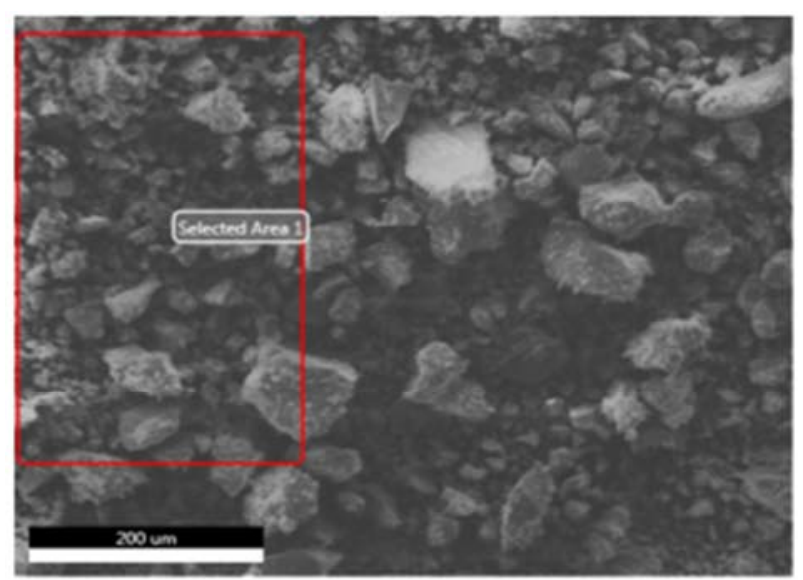




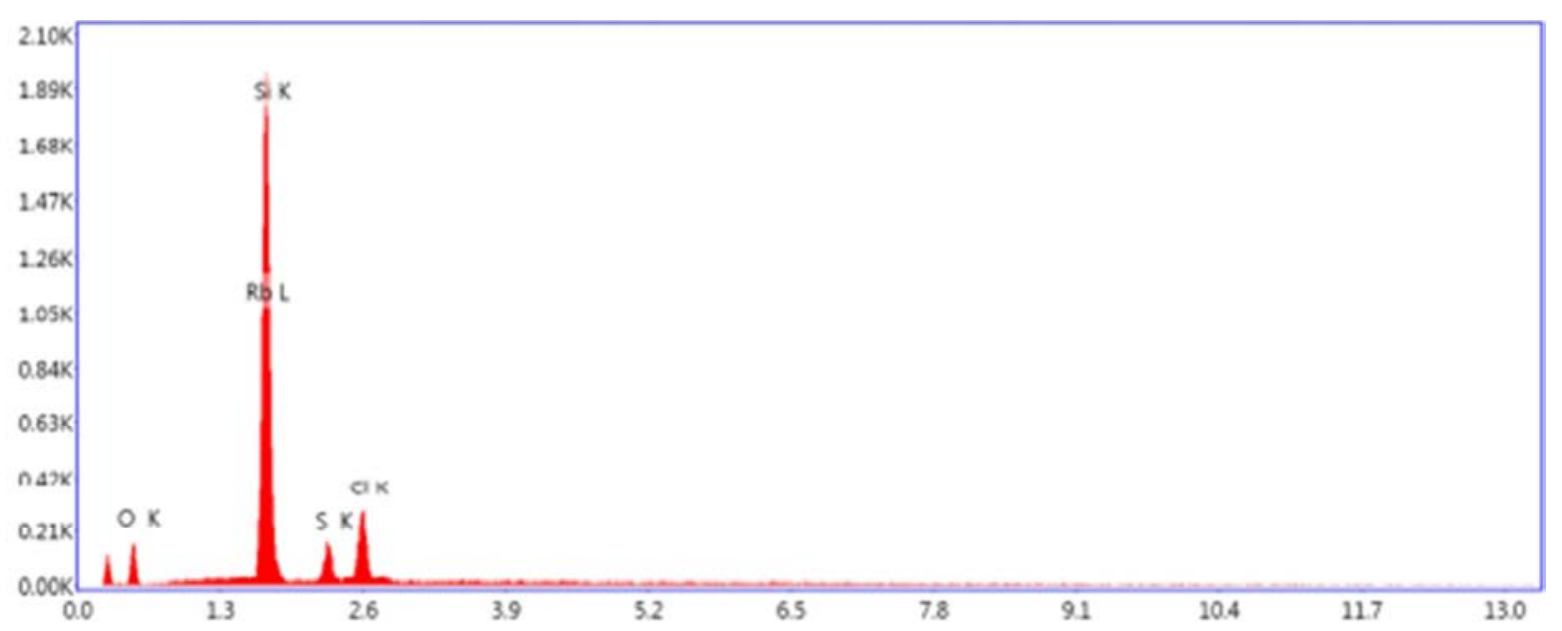

Figure 3. SEM Morphology / EDX Spectrum of Immobilized Thiosalicylic Acid Ligand System.

Table 1. Polysiloxane Immobilized Thiosalicylic Ligand Particle Size (nm) Analysis.

\begin{tabular}{|c|c|c|c|c|c|c|c|c|}
\hline & Area (nm) & Mean & Min & Max & $\mathbf{r}^{2}$ & $\mathbf{r}(\mathrm{nm})$ & d (nm) & $\mathrm{v}\left(\mathrm{nm}^{3}\right)$ \\
\hline Mean & 11.1706 & 255 & 255 & 255 & 3.5557 & 1.7198 & 3.4397 & 52.9940 \\
\hline Standard Error & 1.5278 & 0 & 0 & 0 & 0.4863 & 0.1237 & 0.2475 & 9.9847 \\
\hline Median & 7.932 & 255 & 255 & 255 & 2.5248 & 1.5889 & 3.1779 & 25.2074 \\
\hline Mode & 2.644 & 255 & 255 & 255 & 0.8416 & 0.9173 & 1.8347 & 4.8511 \\
\hline Standard Deviation & 9.6631 & 0 & 0 & 0 & 3.0758 & 0.7829 & 1.5659 & 63.1494 \\
\hline Sample Variance & 93.3771 & 0 & 0 & 0 & 9.4610 & 0.6130 & 2.4522 & 3987.846 \\
\hline Range & 29.083 & 0 & 0 & 0 & 9.2574 & 2.2605 & 4.5210 & 196.799 \\
\hline Maximum & 31.727 & 255 & 255 & 255 & 10.0990 & 3.1778 & 6.3557 & 201.6502 \\
\hline Sum & 446.827 & 10200 & 10200 & 10200 & 142.2295 & 68.7954 & 137.591 & 2119.762 \\
\hline Count & 40 & 40 & 40 & 40 & 40 & 40 & 40 & 40 \\
\hline Confidence Level (95.0\%) & 3.0904 & 0 & 0 & 0 & 0.9837 & 0.2504 & 0.5008 & 20.1961 \\
\hline
\end{tabular}

Foot note: $\mathrm{r}=$ radius, $\mathrm{d}=$ diameter, $\mathrm{v}=$ volume

Table 2. Elemental Composition of Polysiloxane, Functionalized and Immobilized Ligand Systems.

\begin{tabular}{|c|c|c|c|c|c|}
\hline \multirow{2}{*}{ ADSORBENTS } & \multicolumn{5}{|c|}{ ELEMENTS } \\
\hline & $\mathbf{O}(\mathbf{K})$ & $\mathbf{S i}(\mathbf{K})$ & $\mathrm{Cl}(\mathrm{K})$ & $\mathbf{S}(\mathbf{K})$ & $\mathbf{R b}(\mathbf{L})$ \\
\hline 3-Chloropropylpolysiloxane (3CPP) & 25.02 & 50.45 & 24.57 & - & - \\
\hline Functionalized 3CPP & 58.68 & 41.32 & - & - & - \\
\hline Immobilized Thiosalicylic Ligand & 24.79 & 33.68 & 13.85 & 7.14 & 20.54 \\
\hline
\end{tabular}

Note: K, L and M Represent shells or orbitals. O (Oxygen); Si (Silicon); Cl (Chlorine); S (thiol); Rb (Rubidium)

\subsection{Effect of $\mathrm{pH}$}

The leather industry generates wastewater without proper treatment, thereby contaminating the eco-system [24, 25]. As a result of that PITSMCBLS was employed to extract heavy metals $\left(\mathrm{Cr}^{3+}, \mathrm{Fe}^{3+}, \mathrm{Pb}^{2+}, \mathrm{Cu}^{2+}\right.$ and $\left.\mathrm{Zn}^{2+}\right)$ available in the wastewater. This was made possible due to the availability of reactive sites in the polysiloxane matrix in Figure 1. The mechanism could be surface adsorption or chemisorption. The deprotonation of $\mathrm{COOH}$ to $\mathrm{COO}^{-}$by triethylamine, $\mathrm{SH}$, to $\mathrm{S}^{-}$, and the presence of oxy-ions contributed to their extractions. The results for the effect of $\mathrm{pH}$ on the purification of the metals are presented in Table 3 . There was a gradual increase in the extraction from $\mathrm{pH} 2$ to a maximum at $\mathrm{pH} 6$ mostly, which was within the limit of 5.5-7.0 [25] recorded using aminopolysiloxane for similar adsorption studies [26]. Above pH 6, the removal efficiency decreased as the $\mathrm{pH}$ increased to $\mathrm{pH}$ 9, which promoted the precipitation of metal hydroxide in solution.

Table 3. Adsorption Equilibrium for Immobilized Thiosalicylic Acid Ligand System after Treatment of Tannery Wastewater.

\begin{tabular}{lllllll}
\hline \multirow{2}{*}{ METAL } & Conc. & $\mathbf{p H}$ & $\mathbf{6}$ & $\mathbf{6}$ & $\mathbf{7}$ & $\mathbf{9}$ \\
\cline { 2 - 7 } & $\mathbf{2}$ & 17.112 & 14.854 & 10.952 & 5.897 & 3.693 \\
& Cia & 17.112 & 14.854 & 10.952 & 5.897 & 3.693 \\
Cr (ppm) & Cib & 15.368 & 11.999 & 0.28 & 0.514 & 1.136 \\
& Cfa & 15.368 & 11.999 & 0.28 & 0.514 & 1.136 \\
& Cfb & 10.192 & 19.22 & 97.443 & 91.284 & 69.239 \\
\hline
\end{tabular}




\begin{tabular}{|c|c|c|c|c|c|c|}
\hline \multirow{2}{*}{ METAL } & \multirow{2}{*}{ Conc. } & \multicolumn{5}{|l|}{ pH } \\
\hline & & 2 & 4 & 6 & 7 & 9 \\
\hline \multirow{5}{*}{$\mathrm{Fe}(\mathrm{ppm})$} & Cia & 4.224 & 1.619 & 0.328 & 0.732 & 0.272 \\
\hline & $\mathrm{Cib}$ & 4.224 & 1.619 & 0.328 & 0.732 & 0.272 \\
\hline & $\mathrm{Cfa}$ & 1.205 & 0 & 0 & 0 & 0 \\
\hline & $\mathrm{Cfb}$ & 1.205 & 0 & 0 & 0 & 0 \\
\hline & $\% \mathrm{ADS}$ & 0.715 & 100 & 100 & 100 & 100 \\
\hline \multirow{5}{*}{$\mathrm{Pb}(\mathrm{ppm})$} & $\mathrm{Cia}$ & 2.852 & 1.94 & 1.609 & 1.484 & 0.418 \\
\hline & Cib & 2.852 & 1.94 & 1.609 & 1.484 & 0.418 \\
\hline & $\mathrm{Cfa}$ & 0.922 & 0.595 & 0.001 & 0 & 0 \\
\hline & $\mathrm{Cfb}$ & 0.922 & 0.595 & 0.001 & 0 & 0 \\
\hline & $\% \mathrm{ADS}$ & 67.672 & 69.33 & 99.956 & 100 & 100 \\
\hline \multirow{5}{*}{$\mathrm{Cu}(\mathrm{ppm})$} & $\mathrm{Cia}$ & 0.811 & 0.48 & 0.404 & 0.426 & 0.153 \\
\hline & Cib & 0.649 & 0.318 & 0.242 & 0.264 & 0.009 \\
\hline & $\mathrm{Cfa}$ & 0.319 & -0.329 & 0.036 & 0.043 & 0.002 \\
\hline & $\mathrm{Cfb}$ & 0.319 & 0 & 0.036 & 0.043 & 0.007 \\
\hline & $\%$ ADS & 50.847 & 100 & 85.124 & 83.712 & 77.777 \\
\hline \multirow{5}{*}{ Zn (ppm) } & $\mathrm{Cia}$ & 0.177 & 0.02 & 0.051 & 0.039 & -0.003 \\
\hline & $\mathrm{Cib}$ & 0.177 & 0.02 & 0.051 & 0.039 & -0.003 \\
\hline & $\mathrm{Cfa}$ & 0.115 & -0.025 & 0 & 0 & 0 \\
\hline & $\mathrm{Cfb}$ & 0.115 & 0 & 0 & 0 & 0 \\
\hline & $\%$ ADS & 35.028 & 100 & 100 & 100 & 0 \\
\hline
\end{tabular}

Note: $\mathrm{Cia}=$ Initial sample result before subtraction, $\mathrm{Cib}=$ Initial sample result after subtraction $\mathrm{Cfa}=$ Final sample result before subtraction, $\mathrm{Cfb}=\mathrm{Final}$ sample result after subtraction, \%ADS= Percentage adsorption.

\subsection{Effect of PITSLS Dose on the Adsorption of Heavy Metals}

The results in Table 4, shows that, increase in adsorbent dose from $20-30 \mathrm{mg} / 60 \mathrm{~cm}^{3}$ increased the adsorption of metal ion in the solution due to large availability of the surface area at higher concentration of the adsorbent in thiosalicylic with respect to $\mathrm{Cr}^{3+}$. Increase in the adsorbent dose from $10-30 \mathrm{mg} / 60 \mathrm{~cm}^{3}$ had no significant effect on the adsorption of $\mathrm{Fe}^{3+}$ and $\mathrm{Zn}^{2+}$ metal ion in the solution because any further addition of the adsorbent beyond this point did not cause any significant change in the adsorption due to overlapping adsorption sites of the adsorbent particles [27, 28], discrepancies were recorded with respect to $\mathrm{Pb}^{2+}$, which showed significant adsorption at $10 \mathrm{mg} / 60 \mathrm{~cm}^{3}$ and decreased from $20-30 \mathrm{mg} / \mathrm{cm}^{3}$ due to complete overlapping of adsorption sites.

Table 4. Effect of Adsorbent Dosage of PITSLS on the Adsorption of Heavy Metals after Digestion of Tannery Wastewater.

\begin{tabular}{|c|c|c|c|c|}
\hline \multirow{2}{*}{ METAL } & \multirow{2}{*}{ Conc. } & \multicolumn{3}{|c|}{ Adsorbent (mg) } \\
\hline & & 10 & 20 & 30 \\
\hline \multirow{5}{*}{$\mathrm{Cr}(\mathrm{ppm})$} & Cia & 10.952 & 10.952 & 10.952 \\
\hline & $\mathrm{Cib}$ & 10.952 & 10.952 & 10.952 \\
\hline & $\mathrm{Cfa}$ & 0.280 & 0.198 & 0.172 \\
\hline & $\mathrm{Cfb}$ & 0.280 & 0.198 & 0.172 \\
\hline & $\%$ ADS & 97.443 & 98.192 & 98.430 \\
\hline \multirow{5}{*}{$\mathrm{Fe}(\mathrm{ppm})$} & $\mathrm{Cia}$ & 0.328 & 0.328 & 0.328 \\
\hline & $\mathrm{Cib}$ & 0.328 & 0.328 & 0.328 \\
\hline & $\mathrm{Cfa}$ & -0.233 & -0.668 & -0.716 \\
\hline & $\mathrm{Cfb}$ & 0.000 & 0.000 & 0.000 \\
\hline & $\%$ ADS & 100.000 & 100.000 & 100.000 \\
\hline \multirow{5}{*}{$\mathrm{Pb}(\mathrm{ppm})$} & $\mathrm{Cia}$ & 0.418 & 0.418 & 0.418 \\
\hline & $\mathrm{Cib}$ & 0.418 & 0.418 & 0.418 \\
\hline & $\mathrm{Cfa}$ & -0.014 & 0.233 & 0.325 \\
\hline & $\mathrm{Cfb}$ & 0.000 & 0.233 & 0.093 \\
\hline & $\%$ ADS & 100.000 & 44.258 & 22.248 \\
\hline \multirow{5}{*}{$\mathrm{Cu}(\mathrm{ppm})$} & $\mathrm{Cia}$ & 0.404 & 0.404 & 0.404 \\
\hline & $\mathrm{Cib}$ & 0.242 & 0.242 & 0.242 \\
\hline & $\mathrm{Cfa}$ & 0.036 & -0.082 & -0.109 \\
\hline & $\mathrm{Cfb}$ & 0.036 & 0.000 & 0.000 \\
\hline & $\% \mathrm{ADS}$ & 85.124 & 100.000 & 100.000 \\
\hline \multirow{5}{*}{ Zn (ppm) } & Cia & 0.051 & 0.051 & 0.051 \\
\hline & $\mathrm{Cib}$ & 0.051 & 0.051 & 0.051 \\
\hline & $\mathrm{Cfa}$ & -0.002 & -0.069 & -0.070 \\
\hline & $\mathrm{Cfb}$ & 0.000 & 0.000 & 0.000 \\
\hline & $\%$ ADS & 100.000 & 100.000 & 100.000 \\
\hline
\end{tabular}

$\mathrm{rC}_{\mathrm{oi}}=$ relative initial concentration; $\mathrm{rC}_{\mathrm{ef}}=$ relative final concentration, $\% \mathrm{ADS}=$ percentage adsorption 


\subsection{Thermodynamic Study of PITSLS}

The distribution coefficients $\left(\mathrm{K}_{\mathrm{D}}\right)$ for the extraction and percentage adsorption (\% ADS) of $\mathrm{Cr}^{3+}, \mathrm{Fe}^{3+}, \mathrm{Pb}^{2+}, \mathrm{Cu}^{2+}$ and $\mathrm{Zn}^{2+}$ metal ions from solutions of tannery wastewater by Polysiloxane immobilized thiosalicylic ligand system was studied at different temperatures of 303,308 and $313 \mathrm{~K}$ in Table 5. The results for $\left(\mathrm{K}_{\mathrm{D}}\right)$ and $\left(\%\right.$ ADS) ranged from: $\mathrm{Cr}^{3+}$ 287.838 to 296.384 and $\mathrm{Pb}^{2+} 193.788$ to 300.000 and \% ADS for $\mathrm{Cr}^{3+} 96$ to $99 ; \mathrm{Pb}^{2+} 65$ to 100 respectively. This showed that, the distribution coefficients $\mathrm{K}_{\mathrm{D}}$ and \% ADS increased with increase in temperature while $\mathrm{Fe}^{3+}, \mathrm{Cu}^{2+}$ and $\mathrm{Zn}^{2+}$ showed no significant changes with increase in temperature. In order to determine the thermodynamic feasibility and the thermal effects of sorption, the thermodynamic parameters were evaluated using $\Delta \mathrm{G}^{0}=-\mathrm{RT} \operatorname{InK}_{\mathrm{D}}$ and $\Delta \mathrm{G}^{\mathrm{o}}=\Delta \mathrm{H}^{\mathrm{o}}-\mathrm{T} \Delta \mathrm{S}^{\mathrm{o}}$, where $\Delta \mathrm{G}^{\circ}, \Delta \mathrm{H}^{\circ}, \Delta \mathrm{S}^{\circ}$ and $\mathrm{T}$ are Gibbs free energy, enthalpy, entropy and absolute temperature respectively $[6,29]$. $R$ is the gas constant $\left(8.314 \mathrm{Jmol}^{-1} \mathrm{~K}^{-1}\right)$ and $\mathrm{K}_{\mathrm{D}}$ is the equilibrium constant. Plots of $\operatorname{InK}_{\mathrm{D}}$ against $1 / \mathrm{T}$ gave the numerical values of $\Delta \mathrm{H}^{\circ}$ and $\Delta \mathrm{S}^{\circ}$ from slope and intercept respectively [30]. The values of $\Delta \mathrm{G}^{\mathrm{o}}, \Delta \mathrm{H}^{\mathrm{o}}$ and $\Delta \mathrm{S}^{\mathrm{o}}$ are given for $\mathrm{Cr}^{3+}, \mathrm{Fe}^{3+}$, $\mathrm{Pb}^{2+}, \mathrm{Cu}^{2+}$ and $\mathrm{Zn}^{2+}$ in Table 5. The negative values of the Gibbs free energy $\Delta G^{\circ}$ for all temperatures with affinity for polysiloxane immobilized thiosalicylic ligand system towards $\mathrm{Cr}^{3+}, \mathrm{Fe}^{3+}, \mathrm{Pb}^{2+}, \mathrm{Cu}^{2+}$ and $\mathrm{Zn}^{2+}$, suggests spontaneity of the adsorption process which does not required an external. The values for $\Delta \mathrm{G}^{0}$ ranged from $\left(\mathrm{Cr}^{3+}-14.264\right.$ to 14.811; $\mathrm{Fe}^{3+}-14.368$ to $-14.842 ; \mathrm{Pb}^{2+}-13.2676$ to -14.8429 ; $\mathrm{Cu}^{2+}-11.4839$ to -14.8429 and $\mathrm{Zn}^{2+}-14.3686$ to -14.8429 $\mathrm{kJmol}^{-1}$ ). Consequently, $\Delta \mathrm{G}^{\mathrm{o}}$ of $-15 \mathrm{~kJ} / \mathrm{mol}$ are connected with physical interaction between adsorption sites and metal ions which was observed in this work to be less, whereas -30 $\mathrm{kJ} / \mathrm{mol}$ involves charge transfer from adsorbent surface to the metal ion to form a coordination bond this is a total deviation from the results obtained in this work. The positive values: $\Delta \mathrm{H}^{\mathrm{o}}\left(\mathrm{Cr}^{3+} 2.316 ; \mathrm{Fe}^{3+} 0.000 \mathrm{~Pb}^{2+} 105.1305 ; \mathrm{Cu}^{2+} 19.2569\right.$ and $\left.\mathrm{Zn}^{2+} 0.0000 \mathrm{kJmol}^{-1}\right)$, suggest variation of enthalpies accompanying sorption of metal ions on the Polysiloxane immobilized thiosalicylic ligand system (indicating an endothermic process) which is facilitated by higher temperatures. The positive entropy changes: $\Delta \mathrm{S}^{\mathrm{o}}\left(\mathrm{Cr}^{3+}\right.$ 54.750; $\mathrm{Fe}^{3+} 47.421 ; \mathrm{Pb}^{2+}$ 389.328; $\mathrm{Cu}^{2+} 110.9670$ and $\mathrm{Zn}^{2+}$ $47.4214 \mathrm{~J} \mathrm{~mol}^{1} \mathrm{~K}^{1}$ ) is characterized by irregular increase in the randomness at the composite material solution interface during adsorption procedure of the system [31]. The results above are characterized by chemisorption process, favoured at higher temperatures. The thermodynamic parameters considered are in agreement with the work of El-Ashgar et al., [32].

Table 5. Adsorption Thermodynamics of Metal ions Chemisorbed by PITSLS.

\begin{tabular}{|c|c|c|c|c|c|c|c|c|c|c|c|}
\hline $\begin{array}{l}\text { METAL } \\
\text { ION }\end{array}$ & $\mathbf{T}(\mathbf{K})$ & $q_{e}\left(\mathrm{mgg}^{-1}\right)$ & $K_{D}\left(\mathbf{L g}^{-1}\right)$ & $\ln K_{D}$ & $\begin{array}{l}\Delta \mathrm{G}^{\mathbf{O}} \\
\left(\mathrm{KJmol}^{-1}\right)\end{array}$ & $\begin{array}{l}\Delta \mathrm{H}^{\mathrm{O}} \\
\left(\mathrm{KJmol}^{-1}\right)\end{array}$ & $\begin{array}{l}\Delta \mathrm{S}^{\mathrm{O}} \\
\left(\mathrm{Jmol}^{-1} \mathrm{~K}^{-1}\right)\end{array}$ & $\begin{array}{l}\text { Rel.C } C_{i} \\
\text { (ppm) }\end{array}$ & $\begin{array}{l}\text { Rel.C } C_{f} \\
(p p m)\end{array}$ & Cd & $\begin{array}{l}\% \\
\text { ADS } \\
\end{array}$ \\
\hline \multirow{3}{*}{$\mathrm{Cr}^{3+}$} & 303.00 & 3152.40 & 287.837 & 5.662 & -14.264 & \multirow{3}{*}{2.316} & \multirow{3}{*}{54.750} & 10.952 & 0.444 & 10.508 & 96 \\
\hline & 308.00 & 3233.70 & 295.261 & 5.687 & -14.565 & & & 10.952 & 0.173 & 10.779 & 98 \\
\hline & 313.00 & 3246.00 & 296.384 & 5.691 & -14.811 & & & 10.952 & 0.132 & 10.820 & 99 \\
\hline \multirow{3}{*}{$\mathrm{Fe}^{2+}$} & 303.00 & 98.40 & 300.000 & 5.703 & -14.368 & \multirow{3}{*}{0.000} & \multirow{3}{*}{47.421} & 0.328 & 0.000 & 0.328 & 100 \\
\hline & 308.00 & 98.40 & 300.000 & 5.703 & -14.605 & & & 0.328 & 0.000 & 0.328 & 100 \\
\hline & 313.00 & 98.40 & 300.000 & 5.703 & -14.842 & & & 0.328 & 0.000 & 0.328 & 100 \\
\hline \multirow[t]{2}{*}{$\mathrm{Pb}^{2+}$} & 308.00 & 95.00 & 227.512 & 5.427 & -13.897 & \multirow[t]{2}{*}{105.130} & \multirow[t]{2}{*}{389.328} & 0.418 & 0.101 & 0.317 & 76 \\
\hline & 313.00 & 125.00 & 300.000 & 5.703 & -14.842 & & & 0.418 & 0.000 & 0.418 & 100 \\
\hline \multirow{3}{*}{$\mathrm{Cu}^{2+}$} & 303.00 & 23.00 & 95.454 & 4.558 & -11.483 & \multirow{3}{*}{19.256} & \multirow{3}{*}{110.967} & 0.404 & 0.003 & 0.239 & 99 \\
\hline & 308.00 & 24.00 & 300.000 & 5.703 & -14.605 & & & 0.404 & 0.000 & 0.242 & 100 \\
\hline & 313.00 & 24.00 & 300.000 & 5.703 & -14.842 & & & 0.404 & 0.000 & 0.242 & 100 \\
\hline \multirow[b]{2}{*}{$\mathrm{Zn}^{2+}$} & 303.00 & 15.30 & 300.000 & 5.703 & -14.368 & \multirow[b]{2}{*}{0.000} & \multirow[b]{2}{*}{47.421} & 0.051 & 0.000 & 0.051 & 100 \\
\hline & 308.00 & 15.30 & 300.000 & 5.703 & -14.605 & & & 0.051 & 0.000 & 0.051 & 100 \\
\hline
\end{tabular}

\section{Conclusion}

The PITSLS has been prepared and subjected to instrumental methods of analysis such as: FTIR, SEM and EDX the PITSLS showed high potential for the extraction of $\mathrm{Cr}^{3+}, \mathrm{Fe}^{3+}, \mathrm{Pb}^{2+}, \mathrm{Cu}^{2+}$ and $\mathrm{Zn}^{2+}$ at an optimum $\mathrm{pH}$ of 6.0 in the tannery wastewater. This achievement could be employed in the treatment of tannery wastewaters in the industry. Extraction of metal ions increased with the increase in the adsorbent dose and temperature respectively. The thermodynamic parameters suggest a spontaneous and an endothermic affinity of the chelating ligand. The complex formation process is favoured at higher temperatures. The distribution coefficient values increased with increasing temperature indicating that the complex formation process of metal ions $\mathrm{Cr}^{3+}, \mathrm{Fe}^{3+}, \mathrm{Pb}^{2+}, \mathrm{Cu}^{2+}$ and $\mathrm{Zn}^{2+}$ with polysiloxane immobilized thiosalicylic ligand System was accompanied by an absorption of heat.

\section{Authors' Contributions}

This study was conducted between all authors. BULUS HABILA (BH) and E. C. Ezeh (ECE) devised the concept and designed the study. The laboratory investigation, analysis and manuscript draft were performed by $\mathrm{BH}$. Statistical analysis was performed by Jonathan D. G and T. N. B. 
Shekarri (TNBS), S. T. Dahiru (STD), Paul O. Nsude (POS) Emmanuel Agboeze (EA), Ike Christian Ozoemena (ICO) Olajide J. Igbehinadun (OJI), participated in the laboratory work. The final version was written by BH, E C E and Simon Moses, critically reviewed the manuscript for its intellectual content. All the authors gave final approval of the revised version for publication.

\section{Funding}

This research did not receive any specific grants from funding agencies in the public, commercial, or not-for-profit sectors.

\section{Conflicts of Interest}

The authors declare they do not have a conflict of interest.

\section{Acknowledgements}

The authors are grateful to the scholars and technicians of the Department of Pure and Industrial Chemistry, University of Nigeria, Nsukka, Nigeria, and Multi-User Laboratory Ahmadu Bello University Zaria for their moral support and technical assistance during this research. Thanks to Adamu Simon, for his role in the manuscript typesetting.

\section{References}

[1] Habila B., Chidiebere E. E., Hassana D., Joseph I. O and Bwankhot S. T. Determination of heavy metals in tannery wastes, Int. J. Agric. Biosyst. Eng., 2018, 3 (3), 78-81.

[2] Durai G. and Rajasimman M. Biological Treatment of Tannery Wastewater - A Review. Journal of Environmental Science and Technology 4 (1): 1-7.

[3] Islam B. I., Musa A. E., Ibrahim. E. H., Sharafa S. A. A and Elfaki B. M. Evaluation and Characterization of Tannery Wastewater. Journal of Forest Products and Industries, 2014, 3(3), $141-150$.

[4] Muthukkauppan M. and Parthiban P. A Study on The Physicochemical Characteristics of Tannery Effluent Collected from Chennai. International Research Journal of Engineering and Technology (IRJET) 2018, 05 (03): 24-28.

[5] Jahan M. A. A., Akhtar N., Khan N. M. S., Roy C. K., Islam R and Nurunnabi A.. Characterization of Tannery Wastewater and Its Treatment by Aquatic Macrophytes and Algae. Bangladesh J. Sci. Ind. Res. 2014, 49 (4), 233-242.

[6] El-Ashgar. N. M. Extraction and Pre-concentration Capacity of Bi-functionalized Diamine -Thiol Polysiloxane immobilized Ligand System towards Some Divalent Cations. Journal of Iran Chem. Soc., 2009, 6 (4): 823-830.

[7] Issa M. E., Basheer A. E, Kamal A. R. S., Nizam M. E and Ahmed M. E. Polysiloxane-Immobilized Triamine Ligand System, Synthesis and Applications Phosphorus, Sulfur and Silicon, 2002, (177), 741-753.

[8] Salman M. S., Nizam M. E. and Preparation of Immobilized
Polysiloxane Imino(2-aminoethylacetamide) and its Application. The Islamic University Journal Series of Natural Studies and Engineering, 2006, 14 (1), 37-50.

[9] Ali A. S. M., Abdul- Razak N., Ab-Rahman I. Study on the Preparation of a Sol-Gel Sorbent Based Thiosemicarbazone for Selective Removal of Heavy Metal Ions. World applied sciences journal 2012, 16 (8): 1040-1047.

[10] Grzesiak P., Lukaszyk J., Gabala E., Kurczewska J., Schroeder G. The Influence of Silica Functionalized With Silanes on Migration of Heavy Metals In Soil. Polish Journal of Chemical Technology, 2016, 18 (1): 51-57.

[11] Akan J. C., Abdulrahaman F. I., Ogugbuaja V. O., and Reuben K. D. Study of the Physico-Chemical Pollutants in Kano Industrial Areas, Kano State, Nigeria. J. Applied Sci.2009, 4 (2) $89-102$.

[12] Danazumi S. and Bichi M. H. Industrial Pollution and Implication on Source of Challawa River in Kano, Nigeria Int. Journal of Engineering and Technology IJET-IJENS 2010, 10: 01 .

[13] El-Nahhal I. M., El-Ashgar N. M., M. M. Chehimi., Bargiela P., Maquet J., Babonneau F. and Livage J. Metal uptake by porous iminobis (N-2-aminoethylacetamide)-modified polysiloxane ligand system. Microporous Mesoporous, Materials, 2003, 65 (2-3), 299-310.

[14] Nizam M. E. Synthesis and Application of a New Polysiloxane Immobilized Macrocylic Ligand System. Analytical Letters, 2008, 41, 3074-3087.

[15] Shahida P., Ram B. and Dharam S. Assessment of PhysicoChemical Properties of Tannery Waste Water and Its Impact on Fresh Water Quality. International Journal of Current Microbiology and Applied Sciences, 2017, 6 (4), 1879-1887.

[16] Parveen S., Bharose R., and Singh D. Assessment of physicochemical properties of tannery wastewater and its impact on fresh water quality, Int. J. Curr. Microbiol. Appl. Sci., 2017, 6 (4), 1879-1887.

[17] Bernard E., and Jimoh A.. Adsorption of $\mathrm{Pb}, \mathrm{Fe}, \mathrm{Cu}$, and $\mathrm{Zn}$ from Industrial Electroplating Wastewater by Orange Peel Activated Carbon. International Journal of Engineering and Applied Sciences 2013, 4 (2): 95-103.

[18] Senthil K. P and Kirthika K. K. Equilibrium and Kinetic Study of Adsorption of Nickel from Aqueous Solution onto Bael Tree Leaf Powder. Journal of Engineering Science and Technology. 2009, 4 (4): 351-363.

[19] Horsfall. M. J., Abia A. A. and Spiff A. I. Kinetic Studies on the Adsorption of $\mathrm{Cd}^{2+}, \mathrm{Cu}^{2+}$ and $\mathrm{Zn}^{2+}$ Ions from Aqueous Solutions by Cassava (Manihotesculenta) Tuber Bark Waste. Journal Bioresource Technology, 2006, 97 (35): 283-291.

[20] Vasanth K. and Kumar K. Linear and Non-Linear Regression Analysis for the Sorption Kinetics of Methylene Blue onto Activated Carbon Journal of Hazardous Materials, 2006, B137, 1538-1544.

[21] Brad B., Wiacek R., Davidson J., Koonsiripaiboon V., Yantasee W., Shane A. R and Fryxell. G. E. Synthesis of Nanoporous Iminodiacetic Acid Sorbents for Binding Transition Metals. Inorganic Chemistry Communications 2009, 12: 312-315. 
[22] El-Nahhal I. M., El-Ashgar N. M., Abu-Shawish A., Ahmed A and Babonneau F.. Template synthesis of immobilizedpolysiloxane diamine-thiol tetraacetic acid Biligand system and its application for determination of metal ions. Phosphorus, Sulfur Silicon Relat. Elem., 2015, 190 (10), $1646-1657$.

[23] Mona, A. A., Asmah, A., Abu, S., Nizam, M. E., Issa, M. E., Mohammed, M. C., and Florence, B. (2016) Synthesis and Characterization of Immobilized Polysiloxane MonoamineThiol-triacetic acid and its Diamine and Triamine Derivatives. Journal of Sol Gel Technol, 78, 660-672.

[24] Bulus H., Ezeh E. C., Shekarri T. B and Pascalina L. L. Evaluation of Heavy Metal Deposits and distribution in Challawa Industrial Area of Kano Metropolis, Nigeria. Journal of Experimental Research, 2019, Vol 7 (1): 41-48.

[25] Bulus H., Ukoha P. O., Okoduwa S. I. R., Salim A., Babangida M. B. and Simon A.. Synthesis and characterization of an immobilized thiosalicylic-mercaptoethanol biligand system and its application in the detoxification of chromium(III) and iron (III) ions from tannery wastewater New J. Chem., 2020, 44, 2321-2327.

[26] Neudachina L. K. and Lakiza N. V., Complexation of transition metal ions on the surface of carboxylated aminopolysiloxanes, Russ. J. Inorg. Chem., 2014, 59 (6), 632 636.

[27] Siti N. A. A., Mohd H. S. I., K. Lias and Shamsul I.
Adsorption Process of Heavy Metals by Low-Cost Adsorbent: A Review. World Applied Sciences Journal, 2013, 28 (11), 1518-1530.

[28] Zaid A. A and Mohammed S. A. Thermodynamics and Kinetic Studies of Iron (III) Adsorption by Olive Cake in Batch System. Journal of Mexican Chemical Society, 52 (2), 108115 .

[29] Parimalam R., Vairamuthu, R and Ponnusamy S. Adsorption Isotherms, Kinetics, Thermodynamics and Desorption Studies of Reactive Orange16 on Activated Carbon Derived From Ananas Comosus (L.) Carbon. ARPN Journal of Engineering and Applied Sciences 2011, 6, (11): 15-26.

[30] Rajashree K.., Gupta N.., A. K. Kuswaha., Chattopadhyaya M. C. (2012) Determination of Equilibrium, Kinetics and Thermodynamic Parameters for Adsorption of Brilliant Green Dye from Aqueous Solutions onto Eggshell Powder. Indian Journal of Chemical Technology2012, 19: 26-31.

[31] Zhiguang M, N. Di., Zhang F.., Gu P., Liu S. and Liu P. Kinetic and Thermodynamic Studies on the Adsorption of $\mathrm{Zn}^{2+}$ onto Chitosan-aluminium Oxide Composite Material. International Journal of Chemistry 2011, 3 (1): 18-23.

[32] El-Ashgar N. M, Zeyad Y. J. Complexation and Thermodynamic Studies of Polysiloxane Iminobis (NDiethylenediamineacetamide) Ligand System with Some Transition Metal Ions. Physical Chemistry an Indian Journal 2009, 4 (2): 71-76. 